УДК 902.64 https://doi.org/10.24852/2587-6112.2021.4.141.148

\title{
СТЕКЛЯННЫЕ ПОДВЕСКИ ИЗ ПОГРЕБЕНИЙ КОЧЕВНИКОВ ХІІ-ХIV ВВ.
}

\section{(C) 2021 г. Н.П. Курышова}

Стеклянные подвески, происходящие из погребений кочевников XIII-XIV вв. являются массовой категорией находок. Было рассмотрено 63 экземпляра. Основой систематизации подвески стали такие признаки, как технология изготовления и орнаментации, форма, размер и цвет. Подвески как элемент археологического комплекса является важной частью реконструкции костюма. На территории Нижнего Поволжья встречаются погребения хорошей сохранности, в ряде которых выявляется определенный порядок в расположении подвесок, реконструируется способ их ношения. Подвески украшали женский головной убор, становились центром ожерелья и использовались в виде оберегов, служили украшением кошелька или сумочки. Для мужского ордынского костюма характерно использование крупных синих или орнаментированных подвесок в качестве креплений ремешков для предметов вооружения, и украшения кошелька.

Ключевые слова: археология, стеклянные подвески, типология, средневековые кочевники, Золотая Орда, украшения.

\section{GLASS PENDANTS FROM THE BURIALS OF NOMADS OF THE $13^{\mathrm{TH}}-14^{\mathrm{TH}}$ CENTURIES}

\section{N. P. Kuryshova}

Glass pendants originating from the nomad burials of the $13^{\text {th }}-14^{\text {th }}$ centuries form a most numerous category of the finds. A total of 63 items have been studied. The basis for the systematization of the beads is such features as the manufacturing technology, as well as the ornamentation, shape, size and color. Pendants, as a part of the archaeological complex, are an important element of the reconstruction of the costume. The territory of the Lower Volga region features well-preserved burials, in a number of which a certain order in the arrangement of pendants has been traced, and the method of wearing is being reconstructed. Pendants decorated a woman's headdress, formed the center of a necklace, were used in the form of amulets, and also served as a decoration for a purse or bag. The men's costume of the Horde is characterized by the use of large blue or ornamented pendants as retainers for weapon straps, and purse decoration.

Keywords: archaeology, medieval nomads, the Golden Horde, glass pendants, adornments.

Во второй половине XIII-XIV вв. ВолгоДонские степи являлись политическим, экономическим и культурным центром государства Золотая Орда. Именно здесь находились обширные кочевые владения золотоордынских ханов, а также улусы их родственников и ближайшего аристократического окружения. Именно здесь уже в середине XIII в. началось строительство новых торгово-ремесленных центров. В 30-40-х годах XIV в. в результате широкомасштабной градостроительной деятельности ханов Узбека и Джанибека в бассейнах Волги и Ахтубы в небывало короткие сроки сформировались зоны сплошной оседлости, некоторые из которых тянулись вдоль берегов рек на десятки километров. Строительство целого ряда крупных городов, а также множества относительно небольших поселков оказало заметное влияние на повседневную жизнь местного кочевого населения и явилось одной из причин, обусловивших определенное своеобразие кочевни- ческих памятников Волго-Донского региона (Мыськов Е.П., 2015). За этот период в зоне Волго-Донских степей концентрируются и многочисленные погребальные памятники монголо- и тюркоязычных кочевников, в которых стеклянные бусы и подвески становятся массовой категорией находок. По современному административно-территориальному делению этот регион совпадает с территорией Волгоградской области, южными районами Воронежской и Саратовской областей, восточными районами Ростовской области, а также северными районами Астраханской области и северной частью Калмыкии. С юга Волго-Донской регион ограничен рекой Сал, с севера - верховьями реки Медведицы, его восточная граница проходит по линии соляных озер (Эльтон, Боткуль, Баскунчак), а западная - по устью реки Хопер, включая Большую излучину Дона. Объектом исследования послужили подвески из раскопок мавзолеев и грунтовых могильников, подкур- 
ганных захоронений XIII-XIV вв. территории Волго-Донских степей.

Согласно морфологии описания украшений, подвеска - украшение, подвешивающееся к чему-либо. Так, например, серьги в виде «знака вопроса» могли быть дополнены бусиной-привеской, которая в других случаях является отдельной категорией украшений, здесь же становится избыточным элементом. Избыточные элементы - это те, которые так же, как и дополнительные, присоединяются к основе, но в отличие от них представляют собой самостоятельные, законченные вещи (Щапова, 2007, с. 15). Входя в состав украшения, избыточные элементы утрачивают свою самостоятельность и играют роль конструктивных элементов, подчиненных основе. Чаще всего избыточными элементами являются бусины и привески, в составе другого украшения они описываются по соответствующим словарям-классификаторам и в данном исследовании не учитываются.

Здесь же речь пойдет о категории стеклянных подвесок, которые ими являются по своему основному назначению. Это бусины, которые в силу своего размера или особенности формы должны были носиться как отдельные украшения. Учет размеров продолжает схему, предложенную ранее исследователями: где крупными считаются бусы высотой (расстояние между отверстиями) или диаметром больше 10 мм (Валиулина, 1956, с. 86). Как и бусы обычных размеров, мы разделяем подвески по технологии их изготовления и орнаментации. Подвески рассмотрены по типологии, разработанной М.Д Полубояриновой (Полубояринова, 1988, с. 181). Все изученные подвески относятся к одной технологической группе - «изготовление путем навивки стеклянной массы» - и разделяются на две подгруппы: монохромные и орнаментированные. Первая подгруппа делится на отделы и типы по продольному и поперечному сечениям. Вторая подгруппа подразделяется на разряды по способу орнаментации, на отделы по форме поперечного сечения, на типы по форме в продольном сечении.

Группа I. Одноцветные, изготовленные путем навивки на твердый стержень размягченной стеклянной массы.

Подгруппа А. Неорнаментированные.

Отдел І. Круглые.

Тип 1. Зонные (рис. 1: 1; 2: 1-5, 12). Подвески из непрозрачного и полупрозрачного стекла зеленого, синего и белого цветов. Размеры: 11, 15, 3. Найдено 17 экз. Аналогии встречаются в Новгороде в слоях ХІІ-ХІІІ вв. (Щапова, 1956, с. 166), в Саркеле (Львова, 1959, с. 327), в домонгольских памятниках Средней Азии, Херсонесе, в Болгаре (Полубояринова, 2006), в курганах северо-западной Руси XIII-XIV вв., в золотоордынских городах Поволжья и изредка в поздних мордовских могильниках. (Бусятская, 1976, с. 40).

Тип 2. Боченкообразные (рис. 1: 2) из полупрозрачного, темно-синего стекла. Размер 19, 18, 3. Найден 1 экз. Аналогии: подобной формы, но черные, голубые и желтые встречаются в Саркеле (Львова, 1959, с. 327), в Старой Рязани (Монгайт, 1955, с. 176), в КараКоруме (Левашова, 1965, с. 300-301), средневековых слоях Херсонеса и золотоордынских городах Поволжья (Бусятская, 1976, с. 39). В Болгаре известна подвеска коричневого цвета (Полубояринова, 1988, с. 182).

Подгруппа Б. Орнаментированные.

Разряд I. Пятнистые, орнамент в виде 3-6 пятен.

Отдел І. Круглые.

Тип 1. Шарообразные (рис. 1: 3-4; 2: 6-7, 13) подвески из черного непрозрачного стекла, с белыми пятнами; бирюзового цвета с темно-синими пятнами; черного или темносинего цвета с желтыми пятнами. Размеры: 15, 16, 4 (11 экз.). Аналогии встречаются в курганах северо-западной и северо-восточной Руси XI-XIII вв. (Фехнер, 1959, рис. 6, 13), в Болгаре в слоях XII-XIII вв. (Полубояринова, 1988, с. 182), в могильниках Северного Кавказа, в раннесредневековых памятниках Средней Азии, в курганах северо-западной Руси XIII-XIV вв., в позднесредневековых мордовских могильниках, памятниках Хорезма XIIIXIV вв., золотоордынских городах Поволжья (Бусятская, 1976, с. 41).

Разряд II. Подвески с глазчатым узором.

Отдел I. Круглые.

Тип 1. Шарообразные, зонные и эллипсоидные черные, украшенные плоскими реснитчатыми бело-красными глазками (рис. 1: 5; 2 : 14-16) (8 экз.). У более крупных экземпляров вокруг отверстий для нити - рельефный валик из бирюзового стекла. Размеры: 35,29 , 4; 40, 30, 4 (рис. 1: 6; 2: 17). Найдено 3 экз. Такие подвески встречены на Селитренном и Царевском городищах (Бусятская, 1976, с. 44), в Болгаре и на городище Шехрлик (Полубояринова, 1988 , с. 185).

Тип 2. Цилиндрические. Подвески из непрозрачного черного или бирюзового стекла, украшенные плоскими реснитчатыми бело-красными глазками. Размеры: 35, 12 , 

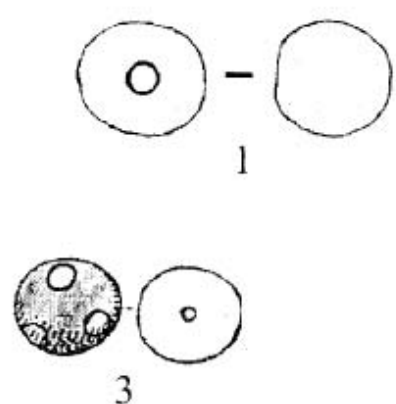

3

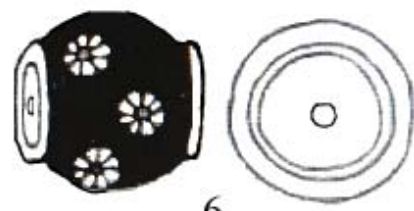

6

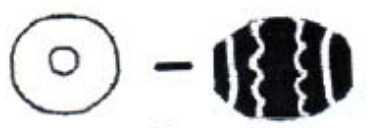

9
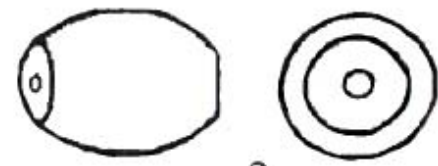

2

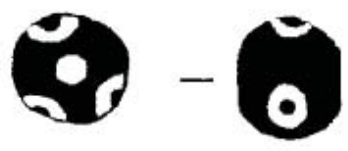

5

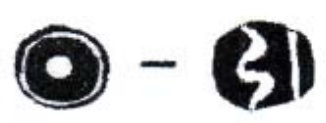

8

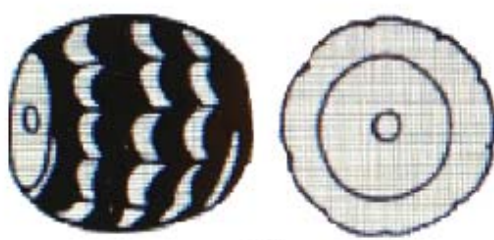

11

Рис. 1. Стеклянные подвески из погребений кочевников XIII-XIV вв.

Fig. 1. Glass pendants from the burials of nomads of the XIII-XIV centuries

4 (рис. 2: 18). Найден 1 экз. Такие подвески встречены на Селитренном и Царевском городищах (Бусятская, 1976, с. 44), в Болгаре и на городище Шехрлик (Полубояринова, 1988, с. 185).

Разряд III. Подвески со спиральной или спирально-волнистой орнаментацией. Орнамент в виде одной или нескольких волнистых линий.

Отдел І. Круглые.

Тип 1. Шарообразные (рис. 1: 7-8; 2: 8-10) бусины-подвески из непрозрачного темносинего или черного стекла, украшенные желтыми или белыми прямыми или волнистыми линиями. Размеры: $15,15,3$. Найдено 8 экз. Аналогии: бусы черного цвета встречаются в позднесредневековых памятниках Хорезма и золотоордынских городах Поволжья (Бусятская, 1976, с. 42).

Тип 2. Боченкообразные (рис. 1: 9-10; 2: 19-20). Подвески из черного или темно-синего непрозрачного стекла, орнаментированы желтыми, белыми, красными нитями. Размеры: 17, 15, 3. Найдено 14 экз. Изредка встречаются красные или зеленые бусины, орнаментированные белыми полосами (рис. 1: 11; 2: 21-22), более крупного размера: $24,24,4$; $30,24,3$. Аналогии: встречаются в русских курганах XIII-XIV вв. (Фехнер, 1959, рис. 6, 24), в Новгороде в слоях XIII-XIV вв. (Щапова, 1956, с. 176), в мордовских могильниках (Алихова, 1948, с. 224), в Болгаре в слоях XII-XIII вв. (Полубояринова, 1988, с. 182), в золотоордынских памятниках Хорезма и золотоордынских городах Поволжья (Бусятская, 1976, с. 42).

Доля крупных бусин-подвесок в общем количестве бус из погребений весьма невелика, в связи с этим интересна их локализация в погребениях.

Подвески встречаются чаще в женских погребениях, погребениях детей и подростков с женским инвентарем. В подавляющем большинстве женских захоронений бусиныподвески располагались у черепа, шейных позвонков, или среди ребер. Судя по расположению подвесок в женских могилах, их обычно носили на шее, либо как самостоятельный единичный подвес, либо в составе «ожерелья-символа» (Каримова, 2013, с. 35), при этом в большинстве захоронений количество бус слишком мало для того, чтобы составить полноценное ожерелье в современном понимании. Изредка одиночные подвески находят у тазовых костей и у голеней, тип этих подвесок в некоторых погребениях локализуется 


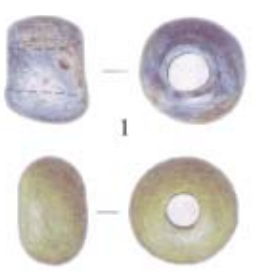

3

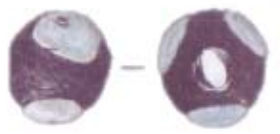

6

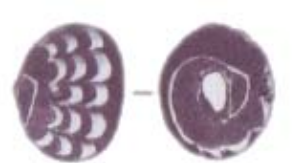

8

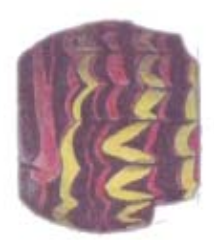

11

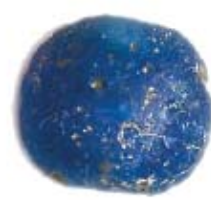

12

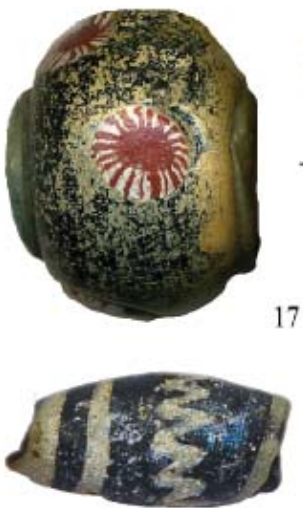

19

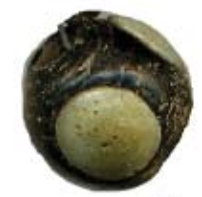

13

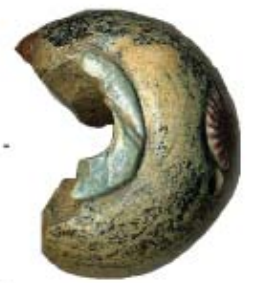

17

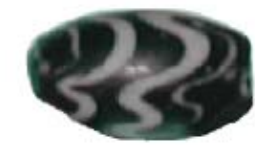

20

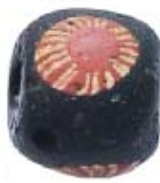

14
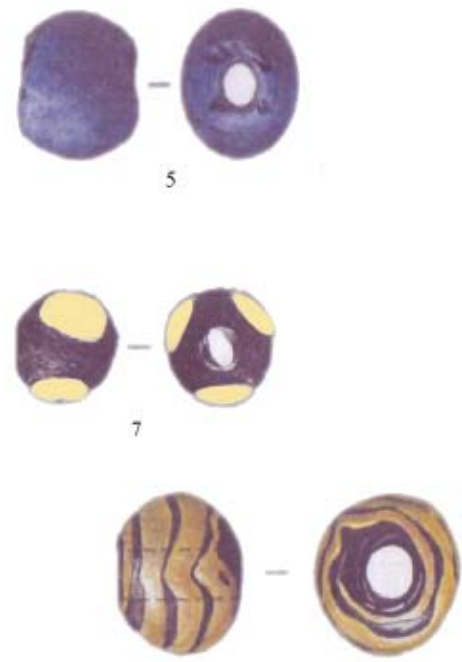

10

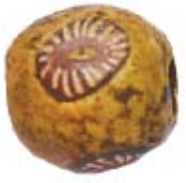

15

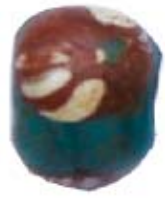

16

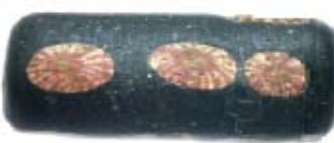

18

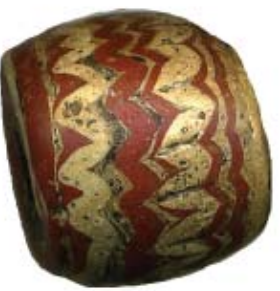

21

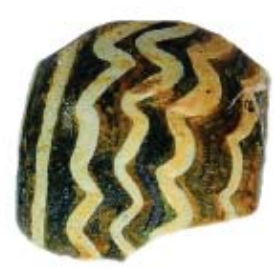

22

Pис. 2. Стеклянные подвески из погребений кочевников XIII-XIV вв.

Fig. 2. Glass pendants from the burials of nomads of the XIII-XIV centuries

в районе головы. Можно предположить, что иногда среди низки мелких бусин, но чаще в они являлись украшением головного убора, поскольку известно, что не всегда головной убор в погребении располагался у головы, иногда его размещали в ногах (Каримова, 2013, с. 50).

В детских погребениях подвески находятся 1-2 экземплярах.

В мужских погребениях преобладают единичные крупные бусины-подвески диаметром от 15 мм и более из темного непрозрачного стекла, большинство из которых украшено белыми глазками или желтыми волнами. в районе груди или среди шейных позвонков, Расположение подвесок в мужских могилах 
Таблица 1. Локализация подвесок в погребениях XIII-XIV вв.

Table 1. Localization of pendants from the burials of nomads of the XIII-XIV centuries.

\begin{tabular}{|c|c|c|c|}
\hline Могильник (курган, погребение) & Пол & Возраст & Локализация в погребении \\
\hline Абганерово III, 14/1; & ж & & На шее, рядом с жемчугом \\
\hline Абганерово III, 7/1 & ж & подросток & $\begin{array}{c}\text { У шеи } \\
\end{array}$ \\
\hline Аткарск, 16/1 & ж & подросток & В районе шеи, в составе низки бус \\
\hline Аткарск, 8 & ж & & Среди шейных позвонков \\
\hline Архара II, 14/1,синяя & & & На шее \\
\hline Бахтияровка, 6/1 & ж & & За черепом \\
\hline Бахтияровка, 28/1 & ж & & У шеи \\
\hline Бахтияровка, 50/1 & Ж & средний возр. & В углу ямы \\
\hline Бахтияровка,69/1 & ж & & У шеи \\
\hline Бахтияровка, 72/1 & ж & & Возле голени \\
\hline Бахтияровка, 110/1 & ж & & У шеи \\
\hline Бахтияровка, 112/1 & ж & & У черепа \\
\hline Веселый II, 1/1 & ж & молодая & В районе шеи, в составе «ожерелья» \\
\hline Венгеловка, 7/1 & Ж & & Возле колен \\
\hline Глазуновский, 5/1 & ж & & У шеи \\
\hline Козинка I, 6/1 & ж & & У шейных позвонков \\
\hline Колобовка II, 4/1; полосат & ж & & На груди, с россыпью бус \\
\hline Ленинск, 42/1 & Ж & & В углу ямы \\
\hline Маляевка, 7/1 & ж & $30-35$ & Возле головы \\
\hline Машевка, 12/1 & ж & & На груди. \\
\hline Нагавский I, 1/1 & ж & & В районе черепа \\
\hline Нижняя Добринка, 1/2 & ж & взрослая & В районе головы \\
\hline Олень-Колодезь, 9/1 & ж & взрослая & В области шеи, с россыпью бус \\
\hline Первомайский I, 11/1 & ж & & В районе головы \\
\hline Пугачев, $1 / 1$ & ж & & $\begin{array}{c}\text { Под шейными позвонками . } \\
\text { В составе «ожерелья» }\end{array}$ \\
\hline Свинуха, 17/1 & ж & молодая & За черепом \\
\hline Свинуха, 18/1 & ж & молодая & У черепа \\
\hline Семенкин, 18/1, & ж & & На груди, в составе «ожерелья» \\
\hline Семенкин, 28/1 & ж & & На груди, в составе «ожерелья» \\
\hline Семенкин, 40/1 & ж & & На груди, в составе «ожерелья» \\
\hline Скатовка, 7/1 & ж & & На груди, в составе «ожерелья» \\
\hline Скатовка, 11/1 & ж & & Среди шейных позвонков \\
\hline Солодовка, 8/2, & ж & & У черепа, на головном уборе \\
\hline Столетовская группа & ж & 30 & На груди. в составе «ожерелья» \\
\hline Суслы, 40/1; & ж & средних лет & Среди ребер \\
\hline Усть-Курдюм, 6/1 & ж & & $\begin{array}{c}\text { В районе грудной клетки. В составе } \\
\text { «ожерелья» }\end{array}$ \\
\hline Харинка, 2/1; & ж & & У шеи. В составе «ожерелья» \\
\hline Царев, 33/1, & ж & & В районе черепа. \\
\hline Штрасбург, 1/1 полос & ж & 30 & У прав руки. \\
\hline Элистинский, 24 & ж & & $\begin{array}{c}\text { На груди у шейных позвонков. } \\
\text { В составе «ожерелья» }\end{array}$ \\
\hline Бахтияровка 47/1 & M & & у ног, рядом кресало \\
\hline Бахтияровка 52/1 & $\mathrm{M}$ & & у черепа, \\
\hline Бахтияровка 76/1 & $\mathrm{M}$ & & в районе шеи \\
\hline Быково III, 11/1 & $\mathrm{M}$ & & у ног, рядом кресало \\
\hline Быково IV, 3/1 & $\mathrm{M}$ & & в области бедер \\
\hline Высокая Гора 2/1 & $\mathrm{M}$ & $35-40$ & у таза \\
\hline Гува, $3 / 1$ & M & & У бедер, рядом кресало \\
\hline Маячный I, 109 & $\mathrm{M}$ & & У таза, рядом кресало \\
\hline Олень-Колодезь, 7/1 & M & взрослый & 0,2 м южнее наконечника копья \\
\hline Покровск 4/1 & M & взрослый & возле конечностей, рядом кресало \\
\hline Салюк, 1 & $\mathrm{M}$ & & в районе бедер \\
\hline
\end{tabular}




\begin{tabular}{|c|c|c|c|}
\hline Салюк, 9 & м & у черепа \\
\hline Царев 10/1 & м & & в углу ямы \\
\hline Шебалино, 2/5 & м & & у ног, рядом кресало \\
\hline Царев 1/1 & м & & У шеи, и у ног, (рядом кресало) \\
\hline Царев 37/1 & м & & у ног, рядом кресало \\
\hline Козинка I, к 4 & м & & на животе \\
\hline Абганерово III, 5/1 & & детский & в области шейных позвонков \\
\hline Бахтияровка, мавзолей/5 & & детский & в области грудной клетки \\
\hline Ленинск, 39/1, & & детский & у шеи \\
\hline Маляевка, 3/1; углу погребения \\
\hline Салюк 24 & & детский & у шеи \\
\hline Солодовка II, 8/1 & & детский & у шеи \\
\hline
\end{tabular}

различно - у бедер, у черепа, у таза, однако в каждом третьем мужском погребении они располагались рядом с железными кресалами и, вероятно, являлись украшениями кисетов или кошельков, в которых эти кресала носили. Либо же подвески являлись своеобразными крепежами-ворворками к ремешкам оружия. Практически во всех мужских погребениях с подвесками были обнаружены предметы вооружения.

В результате исследования мы видим, что подвески не являлись обязательным атрибутом костюма (статистически погребения с бусами составляют лишь $20 \%$ от общего числа изученных кочевнических погребений) (Мыськов, с. 172). Становясь украшением костюма, они сочетали в себе утилитарные функции и играли роль амулетов: в истории известны примеры, когда в кочевом обществе бусы использовались мужчинами в качестве подвесок-амулетов к оружию (221, Мошеева, c. 26). Но чаще всего подвески встречаются в погребениях детей (до 7/8 лет) и женщин фертильного возраста. Видимо, это связано с тем, что пристальный взгляд «дурного глаза» всегда считался особенно вредным для женщин и детей (Жуковская, 2002). Причем использование бус в качестве оберега детьми и женщинами (прежде всего это касается глазчатых бус) характерно и для современной культуры Востока (Мошеева, 2008, с. 28-29, Сазонова, 1970, с. 131).

На основании типологии подвесок можно говорить о том, что подавляющее большинство типов монохромных и орнаментированных стеклянных подвесок из золотоордынских погребений находят прямые аналогии в средневековых памятниках Средней Азии (Бусятская, 1976, с. 43, 66; Галкин, 1984, с. 216-217, 220; Щапова, 1984, с. 224). Достаточно интересны в этом отношении материалы стеклодельной мастерской третьей четверти XIV в., исследованной на Селитренном городище. Здесь обнаружено большое количество различных стеклянных украшений, в том числе и подвески различных типов, некоторые из них представлены как в материалах золотоордынских погребений, так и на средневековых поселениях Хорезма (Галкин, 1984, с. 216). Вследствие широкого ареала распространения подвески фактически становятся частью интернациональной бижутерии и дают представление о моде и цветовых предпочтениях эпохи.

\section{ЛИТЕРАТУРА}

Алихова А.Е. Старосотенский могильник // Археологический сборник. Вып. 1 / Ред. Ю.В. Готье, Н.Ф. Цыганов, Ю.А. Котков. Саранск: Мордовское книжное издательство. 1948. С. 212-258.

Бусятская Н.Н. Стеклянные изделия городов Поволжья (XIII-XIV вв.) // Средневековые памятники Поволжья / Отв. ред. А.П. Смирнов. М.: Наука, 1976. С. 38-72.

Валиулина С.И. Стекло Волжской Булгарии (по материалам Билярского городища). Казань: Казанский государственный университет им. В.И. Ульянова-Ленина, 2005. 280 с.

Галкин Л.Л. Стеклодельная мастерская на городище Селитренное // СА. 1984. № 2. С. 213-221.

Жуковская Н.Л. Кочевники Монголии. Культура. Традиции. Символика. М.: Наука, 2002. 310 с.

Каримова Р.P. Элементы убранства и аксессуары костюма кочевников Золотой Орды (типология и социокультурная интерпретация) / Археология евразийских степей. Вып. 16. Казань: Институт истории им. Ш. Марджани. 2013. 212 с.

Левашова В.П. Бусы из Кара-Корума // Древнемонгольские города / Отв. ред. С.В. Киселев. М.: Наука. 1965. С. 297-307. 
Львова 3. А. Стеклянные браслеты и бусы из Саркела - Белой Вежи // МИА. № 75 / Отв. ред. М.И. Артамонов. М.-Л.: Изд-во АН СССР, 1959.С. 307-332.

Монгайт А.Л. Старая Рязань / Материалы и исследования по археологии древнерусских городов. Т. 4. / МИА. № 49. М.: АН СССР, 1955. 228 c.

Мыськов Е.П. Кочевники Волго-Донских степей в эпоху Золотой Орды. Волгоград: РАНХиГС, 2015. $484 \mathrm{c}$.

Мошеева О.Н. Глазчатые бусы // РА. 2008. № 4. С. 23-33.

Полубояринова М.Д. Стеклянные изделия Болгарского городища // Город Болгар: Очерки ремесленной деятельности / Отв. ред. Г.А. Федоров-Давыдов. М.: Наука, 1988. С. 151-219.

Полубояринова М.Д. Стеклодельная мастерская XIV в. в городе Болгаре // РА. 2006. № 4. С. 57-72.

Сазонова М.B. Украшения узбеков Хорезма // Традиционная культура народов Передней и Средней Азии. Сборник музея этнографии. Т. XXVI. Л.: 1970. С.113-142.

Фехнер М.В. К вопросу об экономических связях древнерусской деревни // Очерки по истории русской деревни X-XIII веков / Труды ГИМ. Вып. 33 / Отв. ред. Б.А. Рыбаков. М.: Советская Россия. 1959. С. 149-224.

Щапова Ю.Л. Стеклянные бусы древнего Новгорода // Труды Новгородской археологической экспедиции. Т. І / МИА. № 55 / Отв. ред. А.В. Арциховский и Б.А. Колчин. М.: АН СССР, 1956. С. 164-179.

Щапова Ю.Л. Химико-технологическое изучение стекол из мастерской на городище Селитренное // CA. 1984. № 2. С. 222-225.

Щапова Ю.Л., Лихтер Ю.А., Сарачева Т.Г., Столярова Е.К. Морфология древностей. Вып 4: морфология украшений. М.: КДУ, 2007. 102 с.

\section{Информация об авторе:}

Курышова Наталья Павловна, аспирант, Казанский федеральный университет (г. Казань, Россия); snejka15@yandex.ru

\section{REFERENCES}

Alikhova, A. E. 1948. In Gotie, Yu. V., Tsyganov, N. F., Kotkov, Yu. A. (eds.). Arkheologicheskii sbornik. (Archaeological Collection of Papers. 1. Saransk: "Mordovskoe knizhnoe izdatel'stvo" Publ., 212-258 (in Russian).

Busiatskaia, N. N. 1976. In Smirnov, A. P. (ed.). Srednevekovye pamiatniki Povolzh'ia (Medieval Sites from the Volga Region). Moscow: "Nauka" Publ., 73-107 (in Russian).

Valiulina, S. I. 2005. Steklo Volzhskoi Bulgarii (po materialam Biliarskogo gorodishcha) (Glass of Volga Bulgaria: by materials of the Bilyar Fortified Settlement). Kazan: Kazan State University (in Russian).

Galkin, L. L. 1984. In Sovetskaia Arkheologiia (Soviet Archaeology) (2), 213-221 (in Russian).

Zhukovskaya, N. L. 2002. Kochevniki Mongolii. Kul'tura. Traditsii. Simvolika (Nomads of Mongolia. Culture. Traditions. Symbolism). Moscow: "Nauka" Publ. (in Russian).

Karimova, R. R. 2013. Elementy ubranstva i aksessuary kostiuma kochevnikov Zolotoi Ordy (tipologiia $i$ sociokul'turnaia interpretatsiia) Elements of dressing and costume accessories of Golden Horde nomads (typology, social and cultural interpretation). Series: Arkheologiia evraziiskikh stepei (Archaeology of the Eurasian Steppes) 7. Kazan: Institute of History named after Shigabuddin Mardzhani, Tatarstan Academy of Sciences; Samara Municipal Institute for Public Administration (in Russian).

Levashova, V. P. 1965. In Kiselev, S. V. (ed.). Drevnemongolskie goroda (Early Mongol Towns). Moscow: "Nauka" Publ., 297-307 (in Russian).

L'vova, Z. A. 1959. In Artamonov, M. I. (ed.). Materialy i issledovaniia po arkheologii SSSR (Materials and Research in the USSR Archaeology) 75. Moscow; Leningrad: the USSR Academy of Sciences, 307-332 (in Russian).

Mongait, A. L. 1955. In Materialy i issledovaniia po arkheologii drevnerusskikh gorodov (Materials and Studies on the Archaeology of Old Russian Towns) 4. Series: Materialy i issledovaniia po arkheologii SSSR (Materials and Studies in Archaeology of the USSR) 49. Moscow: Academy of Sciences of the USSR (in Russian).

Mys'kov, E. P. 2015. Kochevniki Volgo-Donskikh stepei v epokhu Zolotoi Ordy (Nomads of the Volga-Don Steppes in the Golden Horde Period). Volgograd: "RANKhiGS" Publ. (in Russian).

Mosheeva, O. N. 2008. In Rossiiskaia Arkheologiia (Russian Archaeology) (4), 23-33 (in Russian). 
Poluboiarinova, M. D. 1988. In Fedorov-Davydov, G. A. (ed.). Gorod Bolgar. Ocherki remeslennoi deiatel'nosti (City of Bolgar. Essays on Handicrafts). Moscow: "Nauka" Publ., 151-219 (in Russian).

Poluboiarinova, M. D. 2006. In Rossiiskaia Arkheologiia (Russian Archaeology) (4), 57-72 (in Russian).

Sazonova, M. V. 1970. In Kislyakov, N. A. (ed.) Traditsionnaia kul'tura narodov Perednei i Srednei Azii (Traditional Culture of the Peoples of Western and Central Asia). Series: Sbornik Muzeya Antropologii i Etnografii. T. XXVI (Anthropology and Ethnography Museum Collection) 26. Saint Petersburg: "Nauka" Publ., 113-142 (in Russian).

Fekhner, M. V. 1959. In Rybakov, B. A. (ed.). Ocherki po istorii russkoi derevni X-XIII vv. (Essays on History of the Russian Village of $10^{\text {th }}-13^{\text {th }}$ Centuries). Series: Proceedings of the State Historical Museum 33. Moscow: "Sovetskaia Rossiia" Publ., 149-224 (in Russian).

Shchapova, Yu. L. 1956. In Artsikhovskii, A. V., Kolchin, B. A. (eds.). Trudy Novgorodskoi arkheologicheskoi ekspeditsii (Proceedings of the Novgorod Archaeological Expedition) 1. Series: Materialy i issledovaniia po arkheologii SSSR (Materials and Research in the USSR Archaeology) 55. Moscow: Academy of Sciences of the USSR Publ., 165-179 (in Russian).

Shchapova, Yu. L. 1984. In Sovetskaia Arkheologiia (Soviet Archaeology) (2), 222-225 (in Russian).

Shchapova, Yu. L., Likhter, Yu. A., Saracheva, T. G., Stolyarova, E. K. 2007. Morfologiia drevnostei (Morphology of Antiquities) 4. Moscow: "KDU” Publ. (in Russian).

\section{About the Author:}

Kuryshova Natalya P. Kazan (Volga Region) Federal University. Kremlyovskaya St., 18, Kazan, 420000, the Republic of Tatarstan, Russian Federation; snejka15@yandex.ru

Статья поступила в журнал 01.04.2021 г. Статья принята к публикации 01.04.2021 г. 